IRA-International Journal of Management \& Social Sciences

ISSN 2455-2267; Vol.09, Issue 03 (December 2017)

Pg. no. 141-147.

Institute of Research Advances

http://research-advances.org/index.php/RAJMSS

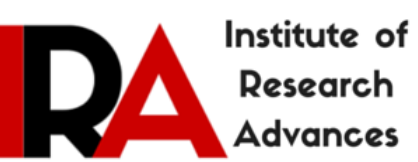

\title{
Does Causal Marketing Matter in the Drugstore Business?
}

\author{
Min-ju Wang ${ }^{1}$; Meng-Chih Shieh ${ }^{2} \mathrm{PhD}$.; Frank Pan ${ }^{3 *} \mathrm{PhD}$. \\ ${ }^{1}$ Graduate Student, Department of Pharmacy, Tajen University, Taiwan. \\ ${ }^{2}$ Associate Professor, Department of Pharmacy, Tajen University, Taiwan. \\ ${ }^{3}$ Associate Professor, Department of Hospitality Management, Tajen University, Taiwan. \\ \#corresponding author. Author's Address: No. 20, Weixin Rd., Yampu, Pingtung, 907, Taiwan. \\ Type of Review: Peer Reviewed. \\ DOI: http://dx.doi.org/10.21013/jmss.v9.n3.p3
}

\begin{abstract}
How to cite this paper:
Wang, M., Shieh, M., Pan, F. (2017). Does Causal Marketing Matter in the Drugstore Business? IRA-International Journal of Management \& Social Sciences (ISSN 2455-2267), 9(3), 141-147. doi:http://dx.doi.org/10.21013/jmss.v9.n3.p3
\end{abstract}

(C) Institute of Research Advances.

(cc) BY-No

This work is licensed under a Creative Commons Attribution-Non Commercial 4.0 International License subject to proper citation to the publication source of the work.

Disclaimer: The scholarly papers as reviewed and published by the Institute of Research Advances (IRA) are the views and opinions of their respective authors and are not the views or opinions of the IRA. The IRA disclaims of any harm or loss caused due to the published content to any party.

Institute of Research Advances is an institutional publisher member of Publishers Inter Linking Association Inc. (PILA-CrossRef), USA. The institute is an institutional signatory to the Budapest Open Access Initiative, Hungary advocating the open access of scientific and scholarly knowledge. The Institute is a registered content provider under Open Access Initiative Protocol for Metadata Harvesting (OAI-PMH).

The journal is indexed \& included in WorldCat Discovery Service (USA), CrossRef Metadata Search (USA), WorldCat (USA), OCLC (USA), Open J-Gate (India), EZB (Germany) Scilit (Switzerland), Airiti (China), Bielefeld Academic Search Engine (BASE) of Bielefeld University, Germany, PKP Index of Simon Fraser University, Canada. 


\begin{abstract}
Drugstore business encountered fierce competition with multiple retailers. Other than professional knowledge and legal protections, drugstores needed to win consumer's trust by creating a favorable image. Based on the theory of planned behavior (TPB), the current research brought the concept of cause-related marketing into the model, and hypothesized that the consumer's perceived cause moderates the relationship within TPB variables. 262 consumers of drugstores were gathered for testing. Test results confirm the applicability of TPB, of which subjective norm is the strongest predictor, followed by perceived behavior control and attitude. Moderating effects of perceived cause existed in the relationship. Several suggestions to industry and the academic were provided.
\end{abstract}

Keywords: Drugstore; Theory of planned behavior; Cause-related marketing

\title{
Introduction
}

In modern business environment as the drugstore business faced, despite that some uniqueness a pharmacist's professional knowledge may create to differentiate the drugstore's image with competitors, price and quality are increasingly equal due to the homogeneous in product source. As a result, value for money is taken by the customers' as a pre-requisite criterion while making choice of shops. Today, consumers are increasingly aware at the brand behind the product or service and the business behind the brand. To create and maintain a quality customer relationship, cause-related marketing (CRM) provides that opportunity for the emotional as well as rational engagement of customers and other stakeholders (Adkins, 1999).

Plenty of literature confirmed that CRM helped businesses enhance reputation and image, improve relationship with their employee, and increase sales and profits as well as consumer's trust (Varadarajan \& Menon, 1988; Adkins, 1999; Drumwright, 1996; File \& Prince,1998; Pringle \& Thompson, 1999; Hartmann, Klink \& Simons,2015). In the meantime, charities also benefit through financial gains and support (Docherty \& Hibbert, 2003; Polonsky \& Wood, 2001) from such partnership.

CRM seems to be most useful for those businesses that highly homogeneous in the market. Drugstores or pharmacies in Taiwan, mainly offers drug dispensing services and sells OTC drugs. One of product lines these drugstores relied to generate good portion of entire profit is the revenue from the sales of healthcare products such as healthy or functional foods, dietary supplements, among others. Consumers can purchase any healthcare products, except those products that were defined as medical products by law. All these had made the drugstores to face compete with not only rival drugstores but also general retailers and chain stores. CRM will bring consumer's trust to the store, enhance drugstore's image, and result in better sales.

This investigation focuses on how consumer's perceived the drugstore have done with cause, and how this perception affects purchasing behavior to that store.

\section{Theory and Literature Review}

\section{Cause-related marketing}

Cause-related marketing (CRM) is defined as the process of formulating and implementing 
marketing activities that are characterized by contributing a specific amount to a designated non profit effort that, in turn, causes customers to engage in revenue providing exchanges (Mullen, 1997).CRM is a commercial activity by which businesses and charities (good causes)work together to form a partnership to market an image for mutual benefit. It is neither philanthropy, nor altruism; it is consumer-lead marketing activity in response to the social demands while devoting to gain consumer's trust and relationship (Farache et al., 2008). Cause-related marketing, as has been suggested, is an extremely effective way of promoting, profiling and leveraging an organization's corporate social responsibility.

Cause-related marketing may be used to activate, facilitate, communicate or demonstrate an image of sponsoring public welfare. Sponsorship, such as sales promotion, public relation, direct marketing, or any other marketing activities, is just part of the marketing mix (Adkins, 1999). This means CRM can be interwoven with any traditional marketing campaigns to manifest the image of sponsorship and to attract the target audience's attention and eventually trust.

\section{What cause}

Causes could be any activities cooperate with not-for-profit organizations that may benefit to the public or to the minorities. Organizations in the following notable subjects, as noted by Gayle L. Gifford (2017), may be considered as source of good causes include organizations on conservation and the environment, public education and human services, on community development, housing and advocacy, on civil liberties and human rights, and in the arts and humanities (Gifford, 2017).

Some notable examples are illustrated hereunder (Institute of Fundraising, IOF, 2015). Case of partnership between Pampers and UNICEF comes as the first. The campaigns initiated at 2003, by which300 million tetanus vaccines have been funded through the Pampers and UNICEF partnership. Brand name of UNICEF added new business for Pampers, and UNICEF received new donations (IOF, 2015). Two other successful cases are also shown how the cooperative parties can be mutual beneficial.

The Big Knit, cooperate between Innocent (a smoothies and drinks producer) and Age UK, by which not only raised money, the campaign has also engaged Age UK's service users in knitting the hats, bringing people together, and helping to tackle social isolation. A donation of 25 pennies is made to Age UK for each hatted bottle, and since 2003 the Big Knit has raised over 1.75 million pounds. The third case regards cooperation The Body Shop and the Women's Aid. The campaign ran from 2004 to 2008 and eventually inspired similar partnerships in 16 countries around the world. The key aim was to raise awareness of domestic violence.

Bear in mind the basic principle on CRM is that a CRM is consumer-lead marketing activities, causes or charities shall be performed to the consumer's favors.

\section{Theory of planned behavior}

Theory of planned behavior (TPB) is very popular theoretical background that was frequently used in a wide variety of human behaviors in management, marketing, healthcare, education, and many others. Extended from the theory of reasoned action (TRA), TPB added a new construct of perceived behavior control (PBC) to gain better explanation (Ajzen, 1985; Armitage \& Conner, 2001). 
As noted and evidenced by the literature, TPB is an easy and stable foundation for researchers to understand the variables behind a behavior. It was found in every field of study, disregarding whether the behavior is within the scope of healthcare or not. In other words, as long as there is a behavior, there is a TPB. The current research attempts to understand the consumer's behavior intention of buying from a particular drugstore, and to test the possible moderating effects of consumer's perception of causes of that drugstore. It is thus appropriate to apply TPB in this study.

TPB take three variables to predict a targeted human behavioral intention. Attitude(AT) or value judgement toward the behavior, subjective norms $(\mathrm{SN})$ or the effects of the significant other' s opinion on the behavior, and the case's perception on the self-confidence, i.e. PBC, on the captioned behavior. AT, SN, and PBC are the three major variables to predict the case's intention toward a behavior (Ajzen, 1985). And the intention is a positive and direct variable to the actions of that behavior (Fishbein \& Ajzen, 1975). The research framework is illustrated as in figure 1

Hypothesis of this research is to test the predictability of attitude, subjective norms, and perceived behavior control, as well as the possible moderating effects of consumer's cause perception on such relationship.

Hypothesis 1: Consumers' attitude and effects of subjective norms toward buying from the drugstore, and perceive behavior control of buying from the drugstore will positively affect the intention of buying from the drugstores.

Hypothesis 2: Consumer's perception of cause toward the drugstore will positively moderated the relationship between predicting variables and buying intention.

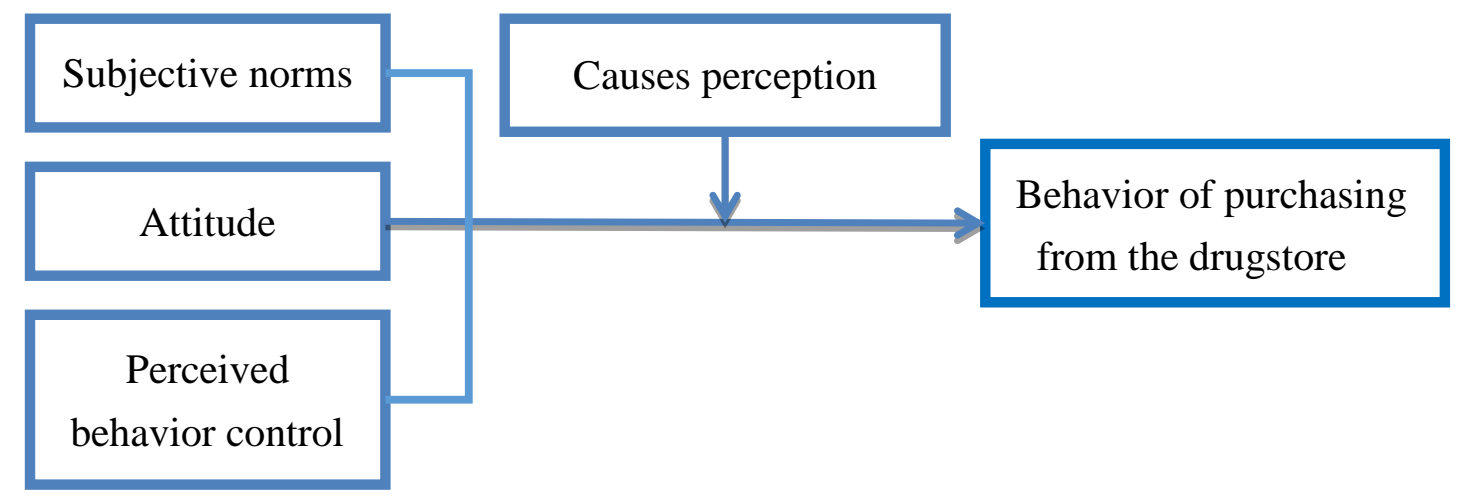

Figure 1 Research framework

\section{Methods}

This study is a survey investigation to be conducted with a structured questionnaire as the measuring instrument (Oluka, Nie \& Sun, 2014). Samples are customers to the selected drugstores in southern Taiwan, and whose owners are members of Taiwan Pharmacist Association. There are 262 valid responses in total.

Statistical analyses applied in this research are descriptive, t-test, multiple regression analyses. Test results associated with discussion are illustrated later. 


\section{Results and discussion}

Sample's profile is illustrated in table 1 . There are 262valid responses from the designated area which was highly air polluted. Women are the majority of the respondents $(64.10 \%)$, about77 percent aged at least 31, most of them are married (59.50\%), and almost all were educated with at least high school diploma.

Table1 Profile of respondents

\begin{tabular}{|c|c|c|c|}
\hline Factor & Category & $\mathrm{n}$ & $\%$ \\
\hline \multirow[t]{2}{*}{ Gender } & Female & 168 & 64.10 \\
\hline & Male & 94 & 35.90 \\
\hline \multirow[t]{5}{*}{ Age } & $30-$ & 62 & 23.70 \\
\hline & $31-40$ & 53 & 20.20 \\
\hline & $41-50$ & 68 & 26.00 \\
\hline & $51-60$ & 55 & 21.00 \\
\hline & $61-70$ & 24 & 9.20 \\
\hline \multirow[t]{3}{*}{ Edu. } & High School or lower- & 51 & 23.30 \\
\hline & College/Bachelor & 172 & 65.60 \\
\hline & Post Graduate & 29 & 11.10 \\
\hline \multirow[t]{3}{*}{ Marital } & Single & 106 & 40.50 \\
\hline & Married & 156 & 59.50 \\
\hline & Sum & 262 & 100.00 \\
\hline
\end{tabular}

This study conducts variance analysis with independent t-test and one-way ANOVA to examine whether the variables varied with personal factors or not. Table 2 shows that personal gender brings different only to the subjective norms. Woman seems more inclined to be affected by their friends or relatives. All variables are varied depends on the factors of age, marital status, and educational levels.

This research conducts a multiple regression analysis to examine how each of the variables contributes to the behavior intention of purchasing from the drugstore. Table 3 shows that the model can explain 38\% variance of intention. Subjective norms appears to be the strongest predictor for the intention $(\beta=0.38)$, followed by the $\operatorname{PBC}(\beta=0.24)$, and attitude $(\beta=0.15), \mathrm{H} 1$ is therefore supported. Table 2 Variables by demographic factors

\begin{tabular}{lllll}
\hline Variables & 1 & 2 & 3 & 4 \\
\hline Intention & & $\mathbf{S}$ & $\mathbf{S}$ & $\mathbf{S}$ \\
Attitude & & $\mathbf{S}$ & $\mathbf{S}$ & $\mathbf{S}$ \\
Subjective norm & $\mathbf{S}$ & $\mathbf{S}$ & $\mathbf{S}$ & $\mathbf{S}$ \\
PBC & & $\mathbf{S}$ & $\mathbf{S}$ & $\mathbf{S}$ \\
\hline
\end{tabular}

1. Gender, 2. Age, 3. Marital, 4. Education; S, significant different at $\mathrm{p}<0.05$

Table 3 Regression analysis

\begin{tabular}{lcccc}
\hline IV & Non-standardized & \multicolumn{1}{l}{ SE } & Standardized & $t$ \\
\hline constant & -0.15 & 0.16 & & $-0.91^{* * * *}$ \\
AT & 0.17 & 0.05 & 0.15 & $4.86^{* * *}$ \\
SN & 0.46 & 0.06 & 0.38 & $8.78^{* * *}$ \\
PBC & 0.32 & 0.06 & 0.24 & $7.41^{* * *}$ \\
\hline D.V.: BI; $R=.62 ; R^{2}=.38 ; A . R^{2}=.36 ; F=207.269, d . f .=3 / 259$ & & \\
\hline
\end{tabular}

$n=262 ;{ }^{*} p<.05 ;{ }^{* *} p<.01 ;{ }^{* * *} p<.001$

We further test the moderating effects of perceived cause in the relationship of predictors and outcomes, as shown in table 4. A represents the respondents has perceived a cause the drugstore performed, whereas B for those not. 
Table 4 Comparing predictors' effects by cause presentation

\begin{tabular}{|c|c|c|c|c|c|}
\hline \multirow{2}{*}{$\begin{array}{l}\text { A(Yes) } \\
\text { Var. }\end{array}$} & \multicolumn{2}{|c|}{ Non-standardized } & \multirow[b]{2}{*}{$\beta$} & \multirow[b]{2}{*}{$t$} & \multirow[b]{2}{*}{$p$} \\
\hline & B & SE & & & \\
\hline constant & -0.97 & 0.37 & & -2.65 & .009 \\
\hline AT & 0.19 & 0.11 & 0.14 & 1.71 & .088 \\
\hline SN & 0.26 & 0.11 & 0.19 & $2.41^{*}$ & .017 \\
\hline $\mathrm{PBC}$ & 0.16 & 0.08 & 0.12 & $2.12^{*}$ & .035 \\
\hline \multicolumn{6}{|c|}{$D V: B I ; R=0.652 ; R^{2}=0.425 ; A d j . R^{2}=0.409 ; F=26.97 * * * ; d . f .=3 / 161$} \\
\hline \multirow{2}{*}{$\begin{array}{l}\text { B (No) } \\
\text { Var. }\end{array}$} & \multicolumn{2}{|c|}{ Non-standardized } & \multirow{2}{*}{$\beta$} & \multirow[b]{2}{*}{$t$} & \multirow[b]{2}{*}{$p$} \\
\hline & B & SE & & & \\
\hline constant & -0.03 & 0.28 & & -0.12 & .904 \\
\hline AT & 0.09 & 0.09 & 0.07 & 1.00 & .320 \\
\hline SN & 0.34 & 0.09 & 0.28 & $3.94^{* * *}$ & .000 \\
\hline PBC & 0.09 & 0.06 & 0.07 & 1.52 & .130 \\
\hline
\end{tabular}

Comparing the regression results of $\mathrm{A}$ (with perceived public welfare) and B (without perceived welfare), model for A has better variance explained that that for B. This means customers behavioral intention are more well explained to those stores that are featured with public welfare promotion campaigns than those are not. While both models indicate customers are significantly affected by subjective norms, the effect of personal behavioral control is only found in customers of model A. People who are more confident with the choice of purchasing more inclined to favor a public welfare program. The test results support the $\mathrm{H} 2$.

\section{Conclusion}

We conclude that the TPB can be applied to explain the consumer's behavioral intention in buying from a particular drugstore, among which the subjective norm is the major predictor, followed by PBC and attitude. Subjective norm, as the strongest predictor, is the only demographic factor that is significant different along with gender. Previous wisdom has shared that women in her 40s are the major decision maker for the family healthcare services and products. This research further indicated that this particular important group of customers can be easily affected by their relatives and friends, as a source of subjective norms. This finding delivers a useful message to the drugstore business management while formulating the marketing plans. Consumer's perceived cause has moderating effects between predictors and intention, we therefore suggest measuring the effect levels of this moderator.

\section{References}

[1] Adkins, S. (1999). Cause-related marketing: who cares wins. Oxford: Butterworth-Heinemann.

[2] Armitage, C. J., \& Conner, M. (2001). Efficacy of the theory of planned behaviour: A meta-analytic review. British Journal of Social Psychology, 40(4), 471-499.

[3] Berkowitz, E. N. (2016). Essentials of health care marketing. Jones \& Bartlett.

[4] Docherty, S., \& Hibbert, S. (2003).Examining company experiences of a UK cause-related marketing campaign. International Journal of Nonprofit and Voluntary Sector Marketing, 8(4), 378-389.

[5] Drumwright, M. E. (1996). Company advertising with a social dimension: the role of noneconomic 
criteria. Journal of Marketing, 60(4), 71-87.

[6] Farache, F., Perks, K. J., Wanderley, L. S. O., \& Sousa Filho, J. M. D. (2008). Cause-related marketing: consumers' perceptions and benefits for profit and non-profits organisations. Brazilian Administration Review, 5(3), 210-224.

[7] File, K. M., \& Prince, R. A. (1998). Cause-related marketing and corporate philanthropy in theprivately held enterprise. Journal of Business Ethics, 17(14), 1529-1539.

[8] Gifford, G. L. (2017). Cause \& Effect.http://www.ceffect.com/clients/.

[9] Hartmann, M., Klink, J., \& Simons, J. (2015). Cause-related marketing in the German retail sector: Exploring the role of consumers' trust. Food Policy, 52(C), 108-114.

[10] Institute of Fundraising (2015). Great examples of Cause-related marketing. https://www.institute-of-fundraising.org.uk/blog/great-examples-of-cause-related-marketing/

[11] Oluka, O. C., Nie, S., \& Sun, Y. (2014). Quality assessment of TPB-based questionnaires: a systematic review. PloS one, 9(4), e94419-e94419.

[12] Polonsky, M. J., \& Wood, G. (2001). Can the over commercialization of cause-related marketing harmsociety? Journal of Macromarkerting, 21(1), 8-22.

[13] Pringle, H., \& Thompson, M. (1999).Brand spirit: how Cause-related marketing builds brands. Chichester: John Wiley \& Sons.

[14] Varadarajan, P. R., \& Menon, A. (1988).Coalignment of marketing strategy and corporate. Journal of Marketing, 52(3), 58-74. 